\title{
Analysis of HLA antigen association with proliferative diabetic retinopathy
}

\author{
P. B. JOHNSTON, M. KIDD, D. MIDDLETON, A. A. GREENFIELD, \\ D..B. ARCHER, C. J. F. MAGUIRE, AND L. KENNEDY
}

From the Department of Ophthalmology, The Queen's University of Belfast, Eye and Ear Clinic, Royal Victoria Hospital, Grosvenor Road, Belfast BT12 6BA

SUMmARY One hundred and thirteen patients with insulin dependent diabetes mellitus for at least 15 years were typed for 22 HLA antigens of the A and B series. Fifty-six patients had severe bilateral proliferative retinopathy and 57 had no retinopathy. There was no statistical difference in frequency of HLA antigens between the 2 groups of diabetic patients. There was a significantly higher frequency of HLA B15 and a significant lower frequency of HLA B14, B17 in the combined diabetic groups than in a control population of 200 normal blood donors.

Proliferative diabetic retinopathy is a major cause of blindness in insulin dependent diabetics. Duration of the disease and hyperglycemia' are important factors influencing development of retinopathy. However, a proportion of patients with long-standing diabetes are found without visible retinopathy. ${ }^{2}$ Pyke and Tattersall ${ }^{3}$ studied the prevalence of diabetic retinopathy in identical twins and suggested that genetic factors may exist which protect or predispose diabetics to retinopathy. Barbosa et al. $^{4}$ and Cudworth et al. ${ }^{5}$ studied histocompatibility antigen frequencies in relation to diabetic eye disease and detected a positive association with HLA B15 and a negative association with HLA B7. This association if confirmed will be helpful in identifying diabetic patients susceptible to proliferative retinopathy.

We studied the frequency of 22 histocompatibility antigens of the A and B series in 2 groups of insulin dependent diabetics which differed only in the presence or absence of proliferative retinopathy.

\section{Patients and methods}

Two groups of patients were selected for study from patients attending the diabetic eye clinic at the Royal Victoria Hospital and were matched for sex, age, duration of diabetes, and age at onset of diabetes. One group of 57 insulin dependent diabetic patients had had the disease for at least 15 years (mean 27.0

Correspondence to Mr P. B. Johnston, FRCS years) without ophthalmoscopic evidence of background or proliferative retinopathy. The age at onset of diabetes was less than $\mathbf{4 0}$ years in every patient (mean 20.3 years). The second group consisted of 56 diabetic patients with severe bilateral proliferative retinopathy treated by panretinal laser photocoagulation. All these patients had been insulin dependent diabetics for at least 15 years (mean 26.2 years) and had a mean age at onset of 18.2 years. Two hundred normal blood donors resident in Northern Ireland were used as a control. ${ }^{6}$

The diabetic patients and control population were typed for 22 HLA antigens of the A and B series by means of a standard 2-stage microlymphocytotoxicity test at $22^{\circ} \mathrm{C}$. The results were analysed statistically by the method described by Edwards.?

\section{Results}

Table 1 shows the frequency of HLA antigens in the 2 diabetic groups and control population. The 2 groups of diabetic patients were compared, and the total chi-square value was 13.65 with 30 degrees of freedom. This is not significant $(p>0 \cdot 10)$, so we cannot infer that there is any difference between the 2 groups of diabetic patients in terms of HLA antigens.

All the diabetics were compared with the control group, and the total chi-square value was 46.38 with 21 degrees of freedom, which is statistically significant $(\mathrm{p}<0 \cdot 005)$. HLA types B14, B15, and B17 were the major contributors. Their combined chi-square value 
Table 1 Frequency of HLA antigens in the diabetic and control groups

\begin{tabular}{|c|c|c|c|c|c|c|c|c|}
\hline \multirow[t]{2}{*}{$\begin{array}{l}H L A \\
\text { antigen }\end{array}$} & \multicolumn{2}{|c|}{$\begin{array}{l}\text { Control } \\
(n=200)\end{array}$} & \multicolumn{2}{|c|}{$\begin{array}{l}\text { Diabetic group proliferative } \\
\text { retinopathy }(n=56)\end{array}$} & \multicolumn{2}{|c|}{$\begin{array}{l}\text { Diabetic group no retinopathy } \\
(n=57)\end{array}$} & \multicolumn{2}{|c|}{$\begin{array}{l}\text { Total diabetic } \\
(n=11.3)\end{array}$} \\
\hline & No. & $\%$ & No. & $\%$ & No. & $\%$ & No. & $\%$ \\
\hline \multirow[t]{8}{*}{ A } & 86 & $43 \cdot 0$ & 28 & $50 \cdot 0$ & 21 & $36 \cdot 8$ & 49 & $43 \cdot 3$ \\
\hline & 91 & $45 \cdot 5$ & 26 & $46 \cdot 4$ & 30 & $52 \cdot 6$ & 56 & $49 \cdot 6$ \\
\hline & 53 & $26 \cdot 5$ & 14 & $25 \cdot 0$ & 14 & $24 \cdot 6$ & 28 & $24 \cdot 8$ \\
\hline & 31 & $15 \cdot 5$ & 10 & $17 \cdot 9$ & 8 & $14 \cdot()$ & 18 & $16 \cdot 0$ \\
\hline & 20 & $10 \cdot()$ & 3 & $5 \cdot 3$ & 3 & $5 \cdot 2$ & 6 & $5 \cdot 3$ \\
\hline & 28 & $14 \cdot 0$ & 7 & $12 \cdot 5$ & 7 & $12 \cdot 3$ & 14 & $12 \cdot 4$ \\
\hline & 10 & $5 \cdot 0$ & 3 & $5 \cdot 4$ & 7 & $12 \cdot 3$ & 10 & $8 \cdot 8$ \\
\hline & 16 & $8 \cdot 0$ & 2 & $3 \cdot 6$ & 6 & $10 \cdot 5$ & 8 & $7 \cdot 1$ \\
\hline \multirow{13}{*}{$\begin{array}{l}3 \\
3 \\
3 \\
3\end{array}$} & 13 & $6 \cdot 5$ & 3 & $5 \cdot 4$ & () & 0 & 3 & $2 \cdot 7$ \\
\hline & 67 & $33 \cdot 5$ & 14 & $25 \cdot 0$ & 11 & $19 \cdot 3$ & 25 & $22 \cdot 1$ \\
\hline & 69 & $34 \cdot 5$ & 28 & 5()$\cdot 0$ & 24 & $42 \cdot 1$ & 52 & $46 \cdot()$ \\
\hline & 54 & $27 \cdot 0$ & 10 & $17 \cdot 9$ & 15 & $26 \cdot 3$ & 25 & $22 \cdot 1$ \\
\hline & 5 & $2 \cdot 5$ & 3 & $5 \cdot 4$ & 1 & $1 \cdot 8$ & 4 & $3 \cdot 5$ \\
\hline & 30 & $15 \cdot 0$ & 3 & $5 \cdot 3$ & 2 & $3 \cdot 5$ & 5 & $4 \cdot 4$ \\
\hline & 9 & $4 \cdot 5$ & 9 & $16 \cdot 1$ & 11 & $19 \cdot 3$ & 20 & $17 \cdot 7$ \\
\hline & 18 & $9 \cdot()$ & 1 & $1 \cdot 8$ & 1 & -1.8 & 2 & $1 \cdot 8$ \\
\hline & 16 & $8 \cdot 0$ & 6 & $10 \cdot 7$ & 6 & $10 \cdot 5$ & 12 & $10 \cdot 6$ \\
\hline & 8 & $4 \cdot()$ & 4 & $7 \cdot 1$ & 4 & $7 \cdot()$ & 8 & $7 \cdot 1$ \\
\hline & 11 & $5 \cdot 5$ & 3 & $5 \cdot 3$ & 5 & $8 \cdot 8$ & 8 & $7 \cdot 1$ \\
\hline & 16 & $8 \cdot 0$ & 4 & $7 \cdot 1$ & 2 & $3 \cdot 5$ & 6 & $5 \cdot 3$ \\
\hline & 20) & $10 \cdot 0$ & 7 & $12 \cdot 5$ & 12 & $21 \cdot 1$ & 19 & $16 \cdot 8$ \\
\hline
\end{tabular}

was $26 \cdot 7$ with 2 degrees of freedom. Without selection this would be significant with $p<0 \cdot 0005$. If the probability is multiplied by $n-3,^{7}$ the significance is $\mathrm{p}<0 \cdot 01$.

Our results indicate that all diabetics are most likely to have HLA B15 and less likely to have HLA B14 and B17. There is no difference in HLA frequency between the 2 groups of diabetic patients.

\section{Discussion}

Several reports suggest a genetic predisposition to diabetic retinopathy. Barbosa et al. ${ }^{8}$ found an association between HLA antigens A1 and B8 with severe diabetic microangiopathy. Larkins et al. ${ }^{9}$ report an association between the pattern HLA B8 without HLA A1 and severe proliferative retinopathy, although we were unable to confirm this observation in a previous report. ${ }^{10}$ Barbosa et al. ${ }^{4}$ Bertrams and Spitznas, ${ }^{11}$ and Cudworth et al. ${ }^{5}$ found that patients with proliferative retinopathy have a strong association with HLA B15, and Barbosa et al. ${ }^{4}$ also observed that diabetic patients with proliferative retinopathy were less often positive for HLA B7. However, Becker et al. ${ }^{12}$ Moller et al. ${ }^{13}$ and Deckert et al. ${ }^{14}$ did not detect a significant difference in HLA antigen frequency between juvenile onset diabetics with and without retinopathy. In the present study we were unable to detect a difference in HLA antigen frequency between 2 groups of juvenile onset diabetics which differed only by the presence of severe proliferative retinopathy or no visible retinopathy.

We found a significant increase in the frequency of HLA B15 in the combined diabetic group which corresponds with other reports. ${ }^{8121315-17}$ A positive association between juvenile onset diabetes and HLA B8 was reported by Cudworth and Woodrow. ${ }^{15}$ We found a high frequency of HLA B8 $(46 \%)$ in our combined diabetic groups, but this was not significantly different from that in the control group of $34.5 \%$. The control group frequency of HLA B8 is high in comparison with results published for other populations apart from a frequency of $34.8 \%$ detected by Reen and O'Regan ${ }^{18}$ in a Southern Irish population. The high frequency of HLA B8 in our control group may mask an association with juvenile onset diabetes which others have found. There was a reduced frequency of HLA B14 and B17 in our combined diabetic group, which has not been reported previously.

We acknowledge the assistance of the Tissue Typing Laboratory at the Belfast City Hospital.

\section{References}

1 Cahill FC. Etzweiler DD. Freinkel N. 'Control' and diabetes. N Engl J Med 1976: 294: 1004.

2 Oakley WG, Pyke DA. Tattersall RB. Watkins PJ. Long term diabetes. QJ Med 1974: 43: 145-56.

3 Pyke DA. Tattersall RB. Diabetic retinopathy in identical twins. Diahetes 1973; 22: 613-18. 
4 Barbosa J, Ramsay RC. Knoblock WH. Cantrill HL. Noreen H. King R. Diabetic retinopathy and HLA. Am J Ophthalmol 1980; 90: $148-53$.

5 Cudworth AG. Bottazzo GF. Doniach D. Genetic and immunological factors in type I diabetes. In: Irvine WJ. ed. Immunology of Diabetes. Edinburgh: Teviot Scientific Publications. 1980: 67-99.

6 Middleton D. Martin J. HLA antigen frequency of Northern Ireland blood donors. Ulster Med J 1978; 47: 171-6.

7 Edwards JH. HLA and disease. J Immunogenet 1974; 1: 249-57.

8 Barbosa J. Noreen H. Emme L. et al. Histocompatibility antigens and diabetic microangiopathy. Tissue Antigens 1976; 7: 233-7.

9 Larkins R. Martin F. Tait B. HLA patterns and diabetic retinopathy. Br Med J 1978; i: 111 .

10 Johnston PB, Middleton D. Archer DB. Hadden DR. HLA antigens in proliferative retinopathy. Int Ophthalmol 1981; 3: 87-9.

11 Bertrams J. Spitznas M. HLA antigens in diabetic retinopathy. Am J Ophthalmol 1981; 91: 120.
12 Becker B, Shin DH, Burgess D. Kilo C, Miller WV. Histocompatibility antigens and diabetic retinopathy. Diabetes 1977; 26: 997-9.

13 Moller E. Persson B. Sterky G. HLA phenotypes and diabetic retinopathy. Diabetologia 1978; 14: 155-8.

14 Deckert T, Egeberg J, Frimodt-Moller C. Sander E, Sverigaard A. Basement membrane thickness, insulin antibodies and HLA antigens in long standing insulin dependent diabetics with and without severe retinopathy. Diabetologia 1979; $17: 91$.

15 Cudworth AG. Woodrow JC. Genetic susceptibility in diabetes mellitus: analysis of the HLA association. Br Med J 1976; ii: 846-8.

16 Nelson PG. Pyke DA. Cudworth AG. Woodrow JC. Histocompatibility antigens in diabetic identical twins. Lancet 1975; ii: 193-4.

17 Chuck AL. Cudworth AG. Plasma fibrinogen, viscosity and HLA phenotypes in relation to the complications of diabetes. Diabetologia 1977; $13: 387$.

18 Reen DJ, O'Regan D. HLA antigen frequencies in an Irish population. Tissue Antigens 1980; 15: 369-72. 